RESEARCH ARTICLE

\title{
Microwave-assisted method for the direct synthesis of nano-sized $\mathrm{Cu}$-zeolite
}

A. Rajapakshe, A. Bandara, R. Weerasooriya and L. Jayarathna*

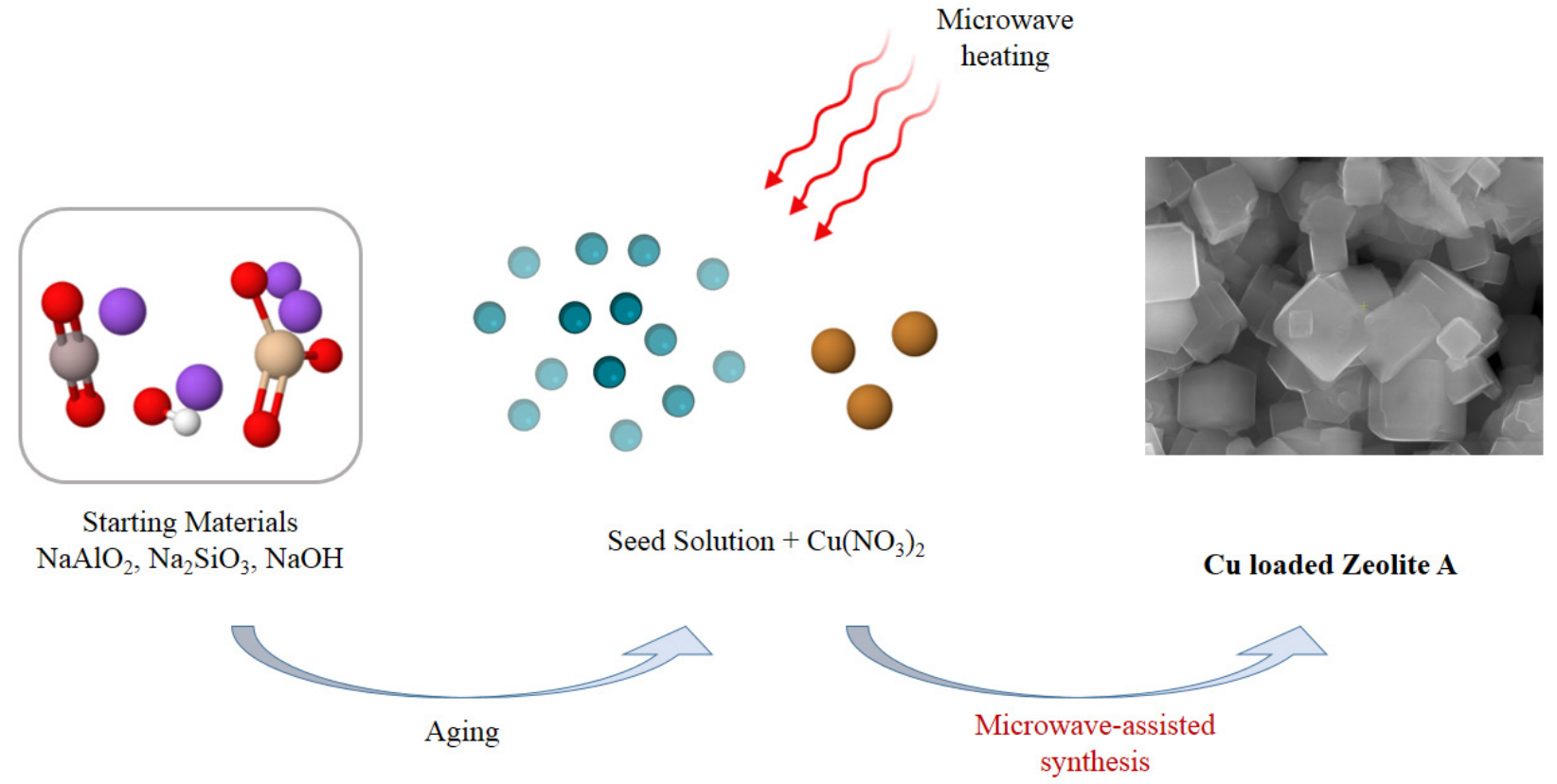

Highlights

- Transition metal incorporation to zeolite is done through conventional ion exchange methods.

- Direct synthesis of $\mathrm{Cu}$ loaded zeolite was carried out via microwave assisted method.

- Low temperature profile provides well crystalline zeolite. 


\title{
RESEARCH ARTICLE
}

\section{Microwave-assisted method for the direct synthesis of nano-sized Cu-zeolite}

\author{
A. Rajapakshe ${ }^{1}$, A. Bandara ${ }^{2}$, R. Weerasooriya ${ }^{1}$ and L. Jayarathna ${ }^{1, *}$ \\ ${ }^{1}$ Environmental Science Research Program, National Institute of Fundamental Studies, Kandy, Sri Lanka. \\ ${ }^{2}$ Department of Chemistry, University of Peradeniya, Peradeniya, Sri Lanka.
}

Received: 12/06/2021; Accepted: 24/09/2021

\begin{abstract}
Recently, the direct synthesis methods for zeolite modification have received much attention from scientists to improve zeolites as catalysts in a variety of applications. Unlike conventional methods, well advanced physicochemical properties could be introduced to zeolites through direct synthesis. During this work, Cu-loaded zeolite was directly synthesized using a microwave-assisted method, and the resulted samples were characterized by Fourier transform infrared spectroscopy (FTIR), powder X-ray diffraction (PXRD), scanning electron microscopy (SEM) and Raman microscopy. The PXRD and SEM results revealed that the $\mathrm{Cu}$-loaded zeolite has LTA(Linde Type A) crystal structure with high crystallinity and particle size obtained within the $300-600 \mathrm{~nm}$ range. The FTIR and Raman microscopic data showed the bond formation of $\mathrm{Cu}$ within the zeolite framework. Unlike other methods, modification of zeolite was done at a low temperature of $110{ }^{\circ} \mathrm{C}$. During this microwave-assisted method, nano-sized, LTA type $\mathrm{Cu}$-zeolite was successfully obtained.
\end{abstract}

Keywords: Copper; direct synthesis; microwave; modification; Zeolite.

\section{INTRODUCTION}

Zeolites are mesoporous materials that can be found in nature, and due to their high demand in various applications, synthetic zeolites are also available widely. Most of the zeolite types are naturally occurred due to volcanic activity (Moshoeshoe et al., 2017). Even though zeolites are utilized in many industries and scientific research during the early 1960s, they have been known for 250 years (Kannangara et al., 2020; Kustov, 2020). Artificial zeolite synthesis was begun during the $19^{\text {th }}$ century, and it was inspired by R.M. Milton and his co-worker, D.W. Breck. As a result, several types of zeolites, such as zeolite A, X and Y, were synthesized (Breck, 1964; Flanigen, 2001; Lutz, 2014; Zimmermann and Haranczyk, 2016).

Zeolites are crystalline aluminosilicates of the alkaline and alkaline earth metal elements. The chemical composition of zeolites is represented by the empirical formula: $\mathrm{M}_{2 / \mathrm{n}} \mathrm{O} \cdot \mathrm{Al}_{2} \mathrm{O}_{3} \cdot \mathrm{ySiO}_{2} \cdot \mathrm{wH}_{2} \mathrm{O}$ (Flanigen, 2001; Dogan, 2003; Hashimoto, 2003; Valdés et al., 2006). Usually, zeolites are composed of a three-dimensional framework of oxygen sharing $\mathrm{AlO}_{4}$ and $\mathrm{SiO}_{4}$ tetrahedral building units. In their structure, some $\mathrm{Si}^{4+}$ ions are substituted by $\mathrm{Al}^{3+}$ ions, originating an anionic framework that arises from the difference of valency between $\left(\mathrm{SiO}_{4}\right)^{4-}$ and $\left(\mathrm{AlO}_{4}\right)^{5-}$ tetrahedra. These resulted negative sites are balanced by counterions, such as alkaline and alkaline earth metal cations. Hence, it reveals the ion exchange property of zeolites (Armbruster and Gunter, 2001; Hashimoto, 2003; Valdés et al., 2006; Tago et al., 2012; Moshoeshoe et al., 2017).

Nowadays, zeolites are synthesized commercially for various applications due to their specific tunable properties, such as porosity, large surface area, thermal stability and ion exchange ability. Due to the cation exchange capability of zeolites, they are widely used in water purification treatments (Kalló, 2001; Kosobucki et al., 2008; Cardoso et al., 2015). On the other hand, zeolites gain much more attention in the industrial sector due to their molecular sieving property. Another significant characteristic property of zeolites is their catalytic activity because of their strong acidic nature. By applying this property of zeolites, they are used in catalytic cracking of long hydrocarbons, production of fine chemical products (Heinemann, 1981), and reduction of harmful gases from vehicle exhaust (Fritz and Pitchon, 1997). Furthermore, with the help of previously mentioned properties, zeolites are utilized in medicinal applications, such as cancer treatment (Moore et al., 1998; Pavelić et al., 2001; Moshoeshoe et al., 2017).

The high interest in nano-sized porous materials is originated with a new era in nanotechnology. The synthesis of nano-sized crystalline zeolites has acquired more consideration because unlike micro-scale zeolites, they have more advanced properties, such as adjustable surface characteristics, large surface area, fine-tuning bulk properties and high stability in suspensions (Zaarour et al., 2013). The capability of these materials to offer sustainable solutions to prevailing global problems is attracted by researchers (Valtchev and Tosheva, 2013). Despite the fact that there are multiple strategies available to synthesize nano-sized zeolites, microwave-assisted technique is more effective than other techniques (Katsuki, 2001). The synthesis of zeolites using microwave heating method has been shown to have many advantages over conventional 
heating methods, such as rapid product formation at low temperature within minimum time period, improved selectivity and improved product uniformity (Panzarella, et al., 2007). Moreover, nowadays, site directing agents are getting more attention because of their ability to control particle size during crystallization (Tago et al., 2012; Abdel et al., 2015; Kannangara et al., 2020).

Recently, strong attention has been directed towards the synthesis of modified zeolite materials using transition metals, such as $\mathrm{Cu}, \mathrm{Fe}, \mathrm{Zn}, \mathrm{Pt}, \mathrm{Pd}, \mathrm{Mn}, \mathrm{Cr}$ and $\mathrm{Ni}$ (Karge and Beyer, 1991; Jiang et al., 2020). There are various applications of modified zeolites, such as the utilization of $\mathrm{TiO}_{2}$ encapsulated zeolite $\mathrm{Y}$ in photovoltaic solar cells (Atienzar et al., 2007), usage of silver containing zeolites as antimicrobial agents (Nagy et al., 2011), usage of copperdoped zeolites as electrochemical sensors (Walcarius, 1999), selective catalytic reduction of $\mathrm{NO}_{\mathrm{x}}$ from vehicle exhaust by Cu-zeolite (Moliner et al., 2012; Giordanini et al., 2013; Mihai et al., 2013) and adsorptive desulfurization by $\mathrm{Cu}(\mathrm{I})-\mathrm{Y}(\mathrm{III})-\mathrm{Y}$ zeolite (Jiang et al., 2020).

The general procedure for zeolite modification is the solid state ion exchange technique (Karge and Beyer, 1991). Other than that, wet ion exchange and chemical vapor deposition ion exchange methods are also mostly used in research fields and industries (Deka et al., 2012). All the above mentioned post-synthetic modification methods are carried out through dealumination, calcination, acid leaching, or chemical treatment steps. The synthesis of modified zeolite with sufficient physicochemical properties for their application in an industrial chemical process has to be improved with the consideration of the overall economic cost of its manufacture. In this manner, the direct synthesis of modified zeolites has received more attention over the multi-step synthesis of zeolite modification (Moliner, 2012). There are various disadvantages that can be found in conventional methods that are used for zeolite modification. Generally, the organic molecules are used as site directing agents which has increased the overall cost of the synthetic procedure. On the other hand, all other multistep methods require high temperature for the calcination process (Sultana, et al., 2011; Deka et al., 2012). The main advantage of inserting transition metals by direct synthesis is correlated to the capability of accomplishing a high dispersion of the metal in the zeolite structure. However, the inclusion of a metal in framework positions is complicated and will depend on the synthesis conditions, such as $\mathrm{pH}$, temperature and source of metal used (Moliner, 2012). In this study, copper loaded zeolite A was synthesized using a microwave heating method and resulted samples were characterized using several techniques.

\section{MATERIALS AND METHODS}

\section{Materials}

Sodium metasilicatepentahydrate (Sigma-Aldrich), sodium aluminate (Sigma-Aldrich), sodium hydroxide (SigmaAldrich) and copper (II) nitrate (Sigma-Aldrich) were used as received without any purification.

\section{Synthesis of zeolite A}

The synthesis of zeolite A via microwave-assisted method was performed as follows: for the microwave-assisted method, MARS 6 microwave digestion system was used. First, a sample of $0.534 \mathrm{~g}$ of $\mathrm{NaOH}$ pellets was dissolved in $5.00 \mathrm{~mL}$ of de-ionized water. Then, a sample of $0.242 \mathrm{~g}$ of $\mathrm{NaAlO}_{2}$ was slowly added into the alkaline solution while shaking. Then, $0.343 \mathrm{~g}$ sample of $\mathrm{Na}_{2} \mathrm{SiO}_{3} .5 \mathrm{H}_{2} \mathrm{O}$ was added and the solution was kept at $60{ }^{\circ} \mathrm{C}$ for $48 \mathrm{~h}$ for aging. Thereafter, the microwave heating was applied to the aged sample with $900 \mathrm{~W}$ at $110{ }^{\circ} \mathrm{C}$ for $3 \mathrm{~h}$. Finally, the synthesized sample was taken out and washed with de-ionized water until washings reached $\mathrm{pH} 8$ and dried at $80{ }^{\circ} \mathrm{C}$ (Kannangara et al., 2020).

\section{Synthesis of $\mathrm{Cu}$-zeolite}

First, the seed solution was prepared as previously mentioned, and it was kept at $60{ }^{\circ} \mathrm{C}$ for $48 \mathrm{~h}$ for aging. Thereafter, $0.5 \mathrm{~mL}$ of $\mathrm{Cu}\left(\mathrm{NO}_{3}\right)_{2}$ was added to the aged sample and a sample series was prepared by varying the $\mathrm{Cu}^{2+}$ concentration from $0.01-1.0 \mathrm{~mol} \mathrm{~L}-1$. Then, the microwave heating was applied to the sample with previously mentioned parameters. Finally, the synthesized sample was taken out and washed with de-ionized water until washings reached $\mathrm{pH} 8$ and dried at $80^{\circ} \mathrm{C}$.

\section{Characterization techniques}

Bond association of the synthesized crystal structure was determined using the FTIR data performed on Thermo Fisher Scientific Nicolet iS 50 FT-IR spectrometer and Raman microscopy measurements were performed using RENISHAW in Via Raman microscope operating with $514 \mathrm{~nm}$ edge LASER state, 2400 1/mm spectrometer state and $10.00 \mathrm{~s}$ of exposure time. Crystallinity and purity of the synthesized products were identified by powder X-ray diffraction (PXRD) technique using a powder X-ray diffractometer (Rigaku-Ultima IV) operating with $\mathrm{Cu}-\mathrm{K}$ radiation $(\lambda=1.54 \AA)$. Scanning electron microscopic (SEM) imaging was conducted for all the samples on EEVO/LS 15 ZEISS microscope .

\section{RESULTS AND DISCUSSION}

\section{Fourier-transform infrared spectroscopy studies}

The FTIR data were collected to determine the bond association within the crystal structure of synthesized samples. The FTIR spectra of synthesized products obtained after microwave-assisted synthesis treatment are shown in Figure 1. As depicted in Figure 1, the absorption bands of the synthesized products show the symmetric and asymmetric vibration bands characteristic of LTA zeolite in the region 400-1200 $\mathrm{cm}^{-1}$ (Barnes et al., 1999). The fingerprint region of the LTA zeolite is considered to be at $400-800 \mathrm{~cm}^{-1}$. The presence of the double rings (D4R and D6R) in the framework zeolite structure is revealed from the bands that appear in the region $650-500 \mathrm{~cm}^{-1}$. The bands in the region $500-420 \mathrm{~cm}^{-1}$ appeared due to the internal tetrahedron vibrations of $\mathrm{Si}-\mathrm{O}$ and $\mathrm{Al}-\mathrm{O}$ of the zeolite structure (Reyes et al., 2013). The region below 
$300 \mathrm{~cm}^{-1}$ is related to $\mathrm{T}-\mathrm{O}-\mathrm{T}$ bending mode and the region $400-550 \mathrm{~cm}^{-1}$ is related to the bending mode of $\mathrm{O}-\mathrm{T}-\mathrm{O}$ ( $\mathrm{T}=\mathrm{Si} / \mathrm{Al}$ ). The asymmetric stretching mode of $\mathrm{T}-\mathrm{O}-\mathrm{T}$ is shown in the region $900-1200 \mathrm{~cm}^{-1}$ while the symmetric stretching mode of $\mathrm{T}-\mathrm{O}-\mathrm{T}$ is shown in the region $550-850 \mathrm{~cm}^{-1}$ (Henderson and Taylor, 1977). The peaks at 461, 557, 665 and $1006 \mathrm{~cm}^{-1}$ which are shown in Figure 1 are related to the LTA zeolite structure. Investigation of the structural changes concerning $\mathrm{Cu}$ and Al-related acid sites can be done by comparison between the band intensities of the individual samples before and after introducing $\mathrm{Cu}$ into zeolite (Mohamed et al., 2017). The sharpness of the band appearing at $665 \mathrm{~cm}^{-1}$ is increased while loading $\mathrm{Cu}$, and it may due to the internal deformation vibration modes of $\mathrm{T}-\mathrm{O}-\mathrm{T}$ bridges. The band at $1006 \mathrm{~cm}^{-1}$ is due to the asymmetrical vibrations related to $(\mathrm{Si}, \mathrm{Al}) \mathrm{O}_{4}$ tetrahedral of zeolite A. However, the sharpness of that peak reduces while increasing the $\mathrm{Cu}$ loading and it may due to the formation of $\mathrm{Cu}-\mathrm{O}$ bonds, and deformation of $\mathrm{Si}-\mathrm{O}$ bonds. This band occurs may be due to $\mathrm{O}-\mathrm{Cu}-\mathrm{O}$ bridge at the covalently bonded $\mathrm{Cu}$ centers. The band at $1647 \mathrm{~cm}^{-1}$ can be assigned to the bending mode of adsorbed water. The presence of a broad band at $3444 \mathrm{~cm}^{-1}$ in $\mathrm{Cu}$-zeolite samples can be assigned to the $\mathrm{O}-\mathrm{H}$ stretching mode and $\mathrm{Cu}-\mathrm{O}$ vibrations. The band intensity slightly reduced while increasing the copper loading to the zeolite A sample. This might be due to decrease in $\mathrm{O}-\mathrm{H}$ bond strength (Fanta et al., 2019).

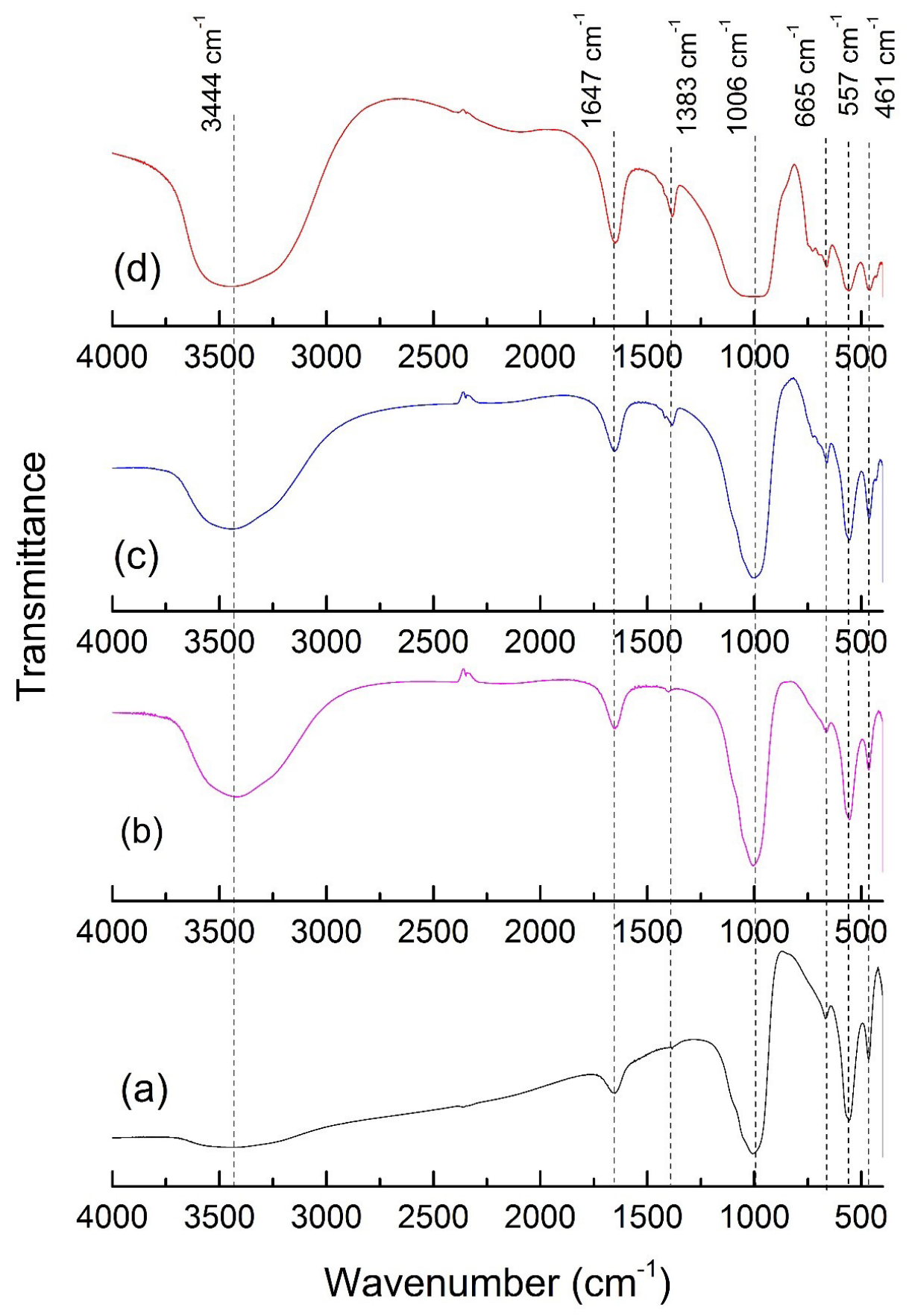

Figure 1: FTIR spectra of (a) synthesized zeolite A (b) Cu-zeolite with $0.01 \mathrm{~mol} \mathrm{~L}^{-1} \mathrm{Cu}^{2+}$ loaded (c) Cu-zeolite with $0.04 \mathrm{~mol} \mathrm{~L}^{-1} \mathrm{Cu}^{2+}$ loaded (d) $\mathrm{Cu}$-zeolite with $1.00 \mathrm{~mol} \mathrm{~L}^{-1} \mathrm{Cu}^{2+}$ loaded. 


\section{Powder X-ray diffraction studies}

To determine the crystal structure and phase transformation of the synthesized zeolite $\mathrm{A}$ and $\mathrm{Cu}$-loaded zeolites, PXRD measurements were taken. The PXRD patterns of zeolite $\mathrm{A}$ and synthesized $\mathrm{Cu}$-zeolites via microwaveassisted synthesis are shown in Figure 2. According to the PXRD pattern, all the samples were found to have higher crystalline nature. The similarity of the PXRD patterns of the $\mathrm{Cu}$-loaded zeolites to that of zeolite $\mathrm{A}$ indicates that the original zeolite structure remains unchanged during modification. Though a slight reduction in the peak intensity after the $\mathrm{Cu}$ loading process was also found as a result of the introduction of metal ions, it may due to the high absorption coefficient of $\mathrm{Cu}$ compounds in $\mathrm{Cu}$-zeolite for the X-ray radiation. As depicted in Figure 2, clear peaks are found at $7.2^{\circ}, 10.1^{\circ}, 12.5^{\circ}, 16.1^{\circ}, 24.0^{\circ}$ and $30.3^{\circ}$ which are characteristic peaks for LTA zeolite (Chudasama et al., 2005). Two additional peaks are observed in the PXRD spectra of $\mathrm{Cu}$-Zeolites at $35.5^{\circ}$ and $38.6^{\circ}$ which are characteristic peaks for $\mathrm{CuO}$ which cannot be observed in the PXRD pattern of synthesized zeolite A (Černík and Padil, 2013). PXRD patterns give minor peaks for $\mathrm{CuO}$ which is not sufficient to identify its phase. The overall results from PXRD pattern suggest the incorporation of copper into the zeolite A framework.

\section{Scanning electron microscopic studies}

To study the particle morphology and the crystal growth process of $\mathrm{Cu}$-loaded zeolites, synthesized samples were characterized using SEM images as shown in Figure 3. Typically, well-developed LTA-type zeolites show cubic morphology in their crystal structure (Reyes et al., 2013). As depicted in SEM images, Cu-loaded zeolites have cubic crystal structure with sharp planer surfaces and well-defined edges. Therefore, it can be suggested that the morphology of zeolite A remain unchanged after the incorporation of copper. Since microwave heating was applied at low temperature, particle size is not much reduced while crystallization and crystals have a particle size distribution of $300-600 \mathrm{~nm}$.

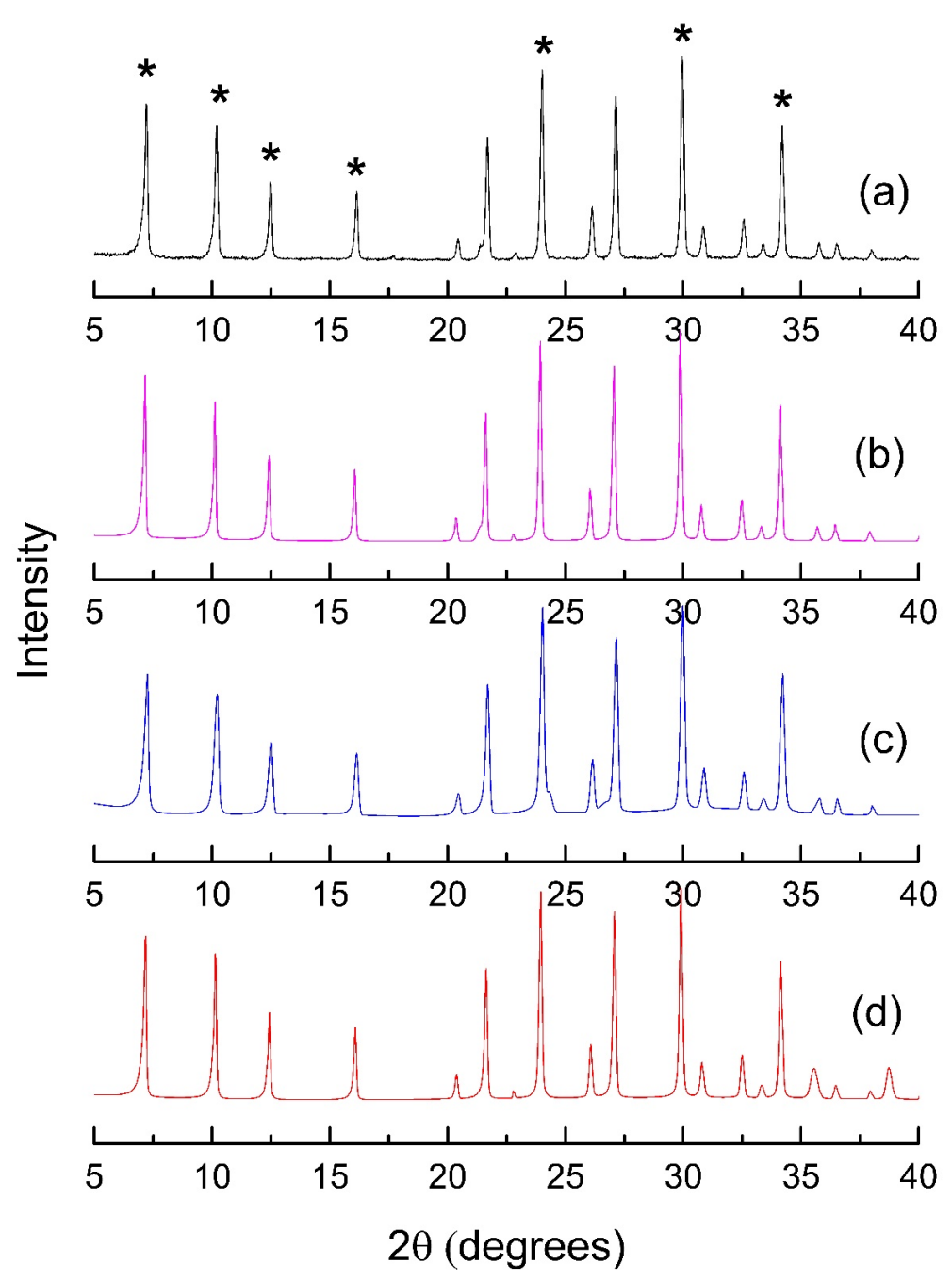

Figure 2: PXRD patterns of (a) Zeolite A (b) Cu-zeolite with $0.01 \mathrm{~mol} \mathrm{~L}^{-1} \mathrm{Cu}^{2+}$ loaded (c) Cu-zeolite with $0.04 \mathrm{~mol} \mathrm{~L}^{-1} \mathrm{Cu}^{2+}$ loaded (d) $\mathrm{Cu}$-zeolite with $1.00 \mathrm{~mol} \mathrm{~L}^{-1} \mathrm{Cu}^{2+}$ loaded.

Peaks in the standard PXRD pattern of Zeolite A are indicated by “*” in the figure. 

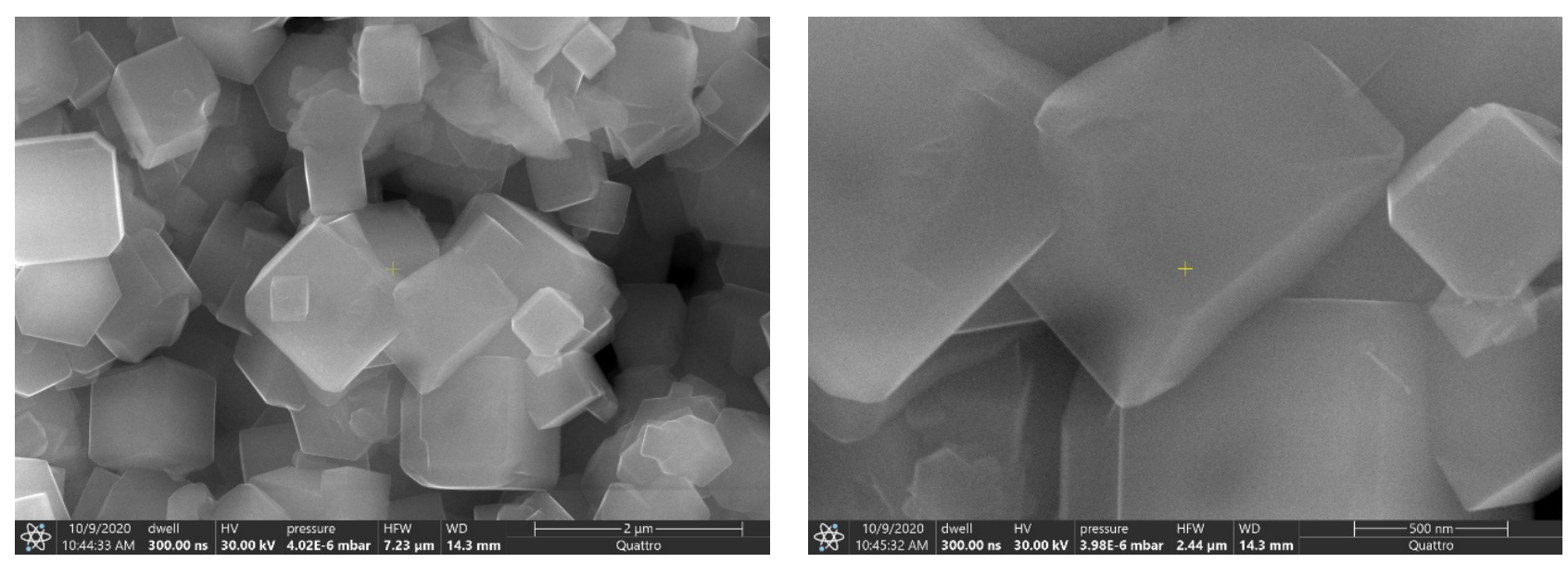

Figure 3: SEM images of Cu-zeolite with $0.04 \mathrm{~mol} \mathrm{~L}^{-1} \mathrm{Cu}^{2+}$ loaded.

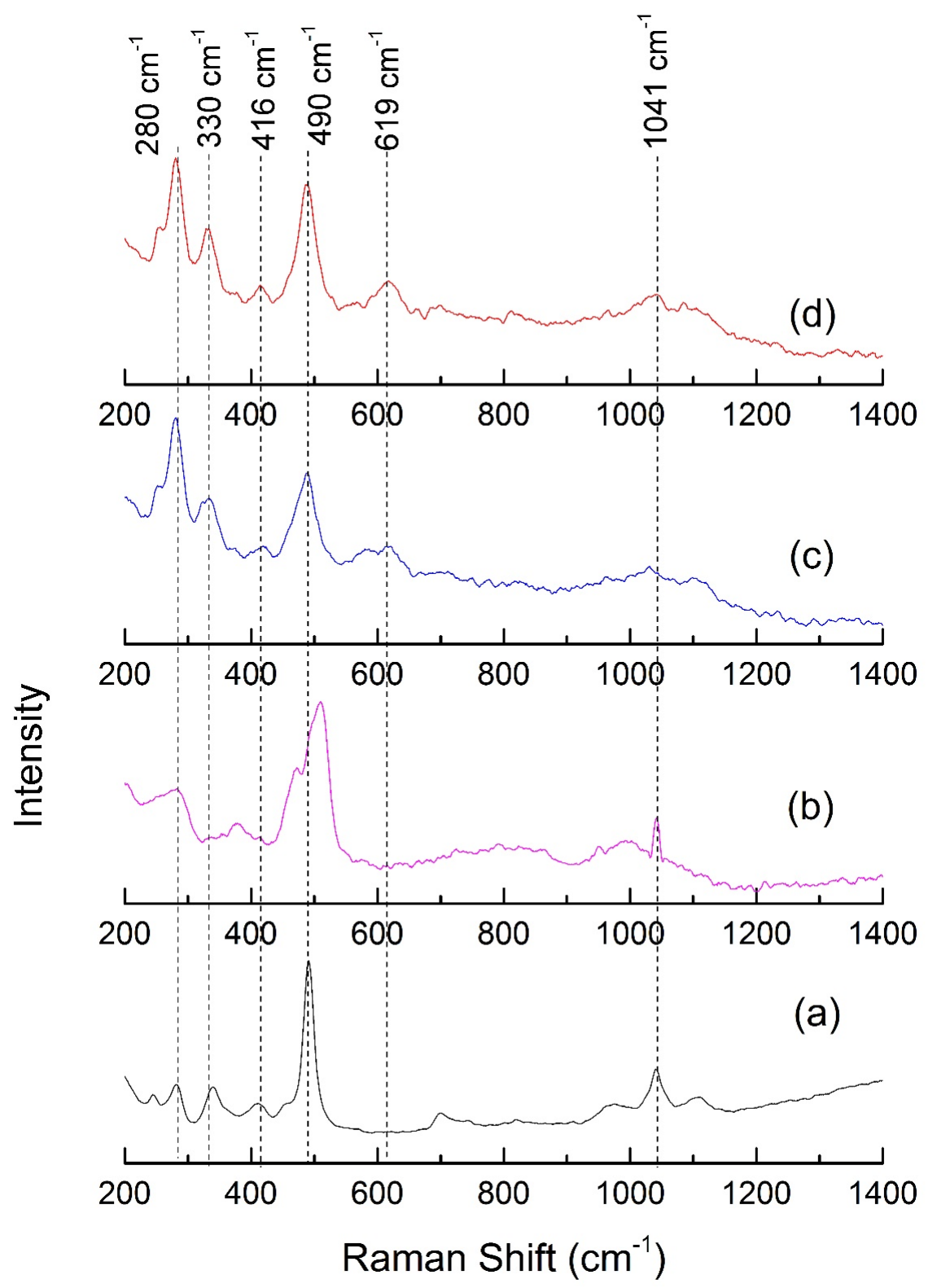

Figure 4: Raman spectra of (a) synthesized zeolite A(b) Cu-zeolite with $0.01 \mathrm{~mol} \mathrm{~L}^{-1} \mathrm{Cu}^{2+}$ loaded (c) Cu-zeolite with 0.04 mol L-1 $\mathrm{Cu}^{2+}$ loaded (d) Cu-zeolite with $1.00 \mathrm{~mol} \mathrm{~L}^{-1} \mathrm{Cu}^{2+}$ loaded. 


\section{Raman microscopic studies}

The Raman microscopic data were collected to determine the bond association within the crystal structure of synthesized samples. Since Raman spectroscopy is complementary to FTIR, it is limited to probing molecules that are IR active. This is because if a bond is strongly polarized, vibrations will have only a small additional effect on polarization, thus exhibiting a weak response on Raman scattering (Juneau et al., 2019). Raman peaks in the spectral region of $380-530 \mathrm{~cm}^{-1}$ reveal the vibration modes of $\mathrm{T}-\mathrm{O}-\mathrm{T}$ bonding, where $\mathrm{T}$ stands for $\mathrm{Si}$ or $\mathrm{Al}$ (Tsai et al., 2021). The bands between $900-1100 \mathrm{~cm}^{-1}$ are corresponded to the $\mathrm{T}-\mathrm{O}$ asymmetric stretching vibrations within the $\mathrm{TO}_{4}$ tetrahedra (Yang et al., 2013). The three bands in the region $900-1100 \mathrm{~cm}^{-1}$ are highly depended on the $\mathrm{Si} / \mathrm{Al}$ ratio and when increasing the $\mathrm{Si} / \mathrm{Al}$ ratio, band broadening and peak intensities are changed. As depicted in Figure 4, zeolite A shows a band at $1041 \mathrm{~cm}^{-1}$ along with weak shoulders at 975 and $1102 \mathrm{~cm}^{-1}$ assigned to $\mathrm{T}-\mathrm{O}$ asymmetric stretching vibrations indicating that the $\mathrm{Si} / \mathrm{Al}$ ratio equal to 1 (Dutta and Del Barco, 1988). Dominant bands in the region $250-550 \mathrm{~cm}^{-1}$ originate from the $\mathrm{T}-\mathrm{O}-\mathrm{T}$ bending vibrations. The bands below $250 \mathrm{~cm}^{-1}$ are frequently associated with the rotational and translational modes of $\mathrm{TO}_{4}$ tetrahedra, as well as the lattice vibrational modes (Yang et al., 2012). It has been reputed that the wavenumbers of Raman bands attributed to the $\mathrm{T}-\mathrm{O}-\mathrm{T}$ bending modes are inversely correlated to the tetrahedral ring size, as well as the $\mathrm{Si} / \mathrm{Al}$ ratio is (Wopenka et al., 1998; Yu et al., 2001; Yang et al., 2013). Yu et al. (2001) proposed that the Raman bands at 470 - 530, 370 - 430, 290 - 410 and $220-280 \mathrm{~cm}^{-1}$ can be related to the bending modes of 4-, 5-, 6-, and 8-membered rings of aluminosilicate zeolites, respectively. As depicted in Figure 4, bands at 280, 330 and $490 \mathrm{~cm}^{-1}$ are assigned to be bending modes of 8-, 6- and 4-membered rings of aluminosilicate zeolites, respectively. The peak at $700 \mathrm{~cm}^{-1}$ is characteristic of the double ring present in the zeolite A framework (Dutta et al., 1992). That peak does not appear in Raman spectra of $\mathrm{Cu}$-loaded zeolites and it can be due to distortion of double rings by copper ions. As shown in Figure 4, with the increase of $\mathrm{Cu}$ loading, peaks in the range $900-1100 \mathrm{~cm}^{-1}$ disappear while a new peak appears at $619 \mathrm{~cm}^{-1}$. This may be due to the weakening of the $\mathrm{T}-\mathrm{O}$ bonds and the formation of $\mathrm{Si}-\mathrm{O}-\mathrm{Cu}$ bonds in the zeolite framework.

\section{CONCLUSION}

The Cu-zeolite was successfully synthesized using a novel microwave-assisted direct synthesis method. The SEM and PXRD results reveal that all the $\mathrm{Cu}$-zeolite samples have formed LTA-type zeolite structures with a high degree of crystallinity. Moreover, according to the results obtained from FTIR spectroscopy and Raman microscopy, the formation of $\mathrm{Si}-\mathrm{O}-\mathrm{Cu}$ bonds and weakening of $\mathrm{Si}-\mathrm{O}$ and $\mathrm{Al}-\mathrm{O}$ bonds in the crystal structure are confirmed. Unlike conventional methods, modification of zeolite was done during this method at a low temperature of $110{ }^{\circ} \mathrm{C}$, and nano-sized, LTA type $\mathrm{Cu}$-zeolite was successfully obtained. Hence, this method could be improved as a cost-effective direct synthesis method in industrial applications.

\section{ACKNOWLEDGEMENT}

The authors wish to acknowledge the financial support extended by National Institute of Fundamental Studies, Kandy, Sri Lanka and National Research Council (NRC) (Grant number NRC-19-090), Sri Lanka.

\section{DECLARATION OF CONFLICT OF INTEREST}

The authors declare no conflict of interest.

\section{REFERENCES}

Abdel, M.O., Ismail, I., Abdelmonem, N. and Abdel, R.R. (2015). Factorial design analysis for optimizing the removal of cesium and strontium ions on synthetic nano-sized zeolite. Journal of the Taiwan Institute of Chemical Engineers 55: 133-144. DOI: https://doi. org/10.1016/j.jtice.2015.04.007.

Armbruster, T. and Gunter, M. (2001). Crystal structures of natural zeolites. Reviews in Mineralogy and Geochemistry 45(1): 1-67. DOI: https://doi. org/10.2138/rmg.2001.45.1.

Atienzar, P., Valencia, S., Corma, A. and García, H. (2007). Titanium-containing zeolites and microporous molecular sieves as photovoltaic solar cells. Chemphyschem 8(7): 1115 - 1119. DOI: https:// doi.org/10.1002/cphc.200700019.

Barnes, M., Addai-Mensah, J. and Gerson, A. (1999). A methodology for quantifying sodalite and cancrinite phase mixtures and the kinetics of the sodalite to cancrinite phase transformation. Microporous and Mesoporous Materials 31(3): 303 - 319. DOI: https:// doi.org/10.1016/s1387-1811(99)00080-3.

Breck, D. (1964). Crystalline molecular sieves. Journal of Chemical Education 41(12): 678. DOI: https://doi. org/10.1021/ed041p678.

Cardoso, A., Horn, M., Ferret, L., Azevedo, C. and Pires, M. (2015). Integrated synthesis of zeolites $4 \mathrm{~A}$ and $\mathrm{Na}-$ P1 using coal fly ash for application in the formulation of detergents and swine wastewater treatment. Journal of Hazardous Materials 287: 69 - 77. DOI: https://doi. org/10.1016/j.jhazmat.2015.01.042.

Černík, M. and Thekkae P.V. (2013). Green synthesis of copper oxide nanoparticles using gum karaya as a biotemplate and their antibacterial application. International Journal of Nanomedicine 8: 889 - 898. DOI: https://doi.org/10.2147/ijn.s40599.

Chudasama, C., Sebastian, J. and Jasra, R. (2005). Poresize engineering of zeolite A for the size/shape selective molecular separation. Industrial and Engineering Chemistry Research 44(6): 1780 - 1786. DOI: https:// doi.org/10.1021/ie0493331.

Deka, U., Lezcano-Gonzalez, I., Warrender, S., Lorena, P.A., Wright, P., Weckhuysen, B. and Beale, A. (2013). Changing active sites in $\mathrm{Cu}-\mathrm{CHA}$ catalysts: $\operatorname{deNO}_{x}$ selectivity as a function of the preparation method. Microporous and Mesoporous Materials 166: 144- 52. DOI: https://doi.org/10.1016/j. micromeso.2012.04.056.

Dogan, A. (2003). Zeolite mineralogy and cappadocian erionite. Indoor and Built Environment 12(5): 337- 
342. DOI: https://doi.org/10.1177/142032603036408.

Dutta, P. and Del, B.B. (1988). Raman spectroscopy of zeolite A: influence of silicon/aluminum ratio. The Journal of Physical Chemistry 92(2): 354 - 357. DOI: https://doi.org/10.1021/j100313a022.

Fanta, F., Dubale, A., Bebizuh, D. and Atlabachew, M. (2019). Copper doped zeolite composite for antimicrobial activity and heavy metal removal from waste water. BMC Chemistry 13(1):44 DOI: https://doi. org/10.1186/s13065-019-0563-1.

Flanigen, E. (2001). Chapter 2 zeolites and molecular sieves: an historical perspective. Studies in Surface Science and Catalysis 137(0167 - 2991): 11 - 35. DOI: https://doi.org/10.1016/s0167-2991(01)80243-3.

Fritz, A. and Pitchon, V. (1997). The current state of research on automotive lean $\mathrm{NO}_{\mathrm{x}}$ catalysis. Applied Catalysis B: Environmental 13(1): 1 - 25. DOI: https:// doi.org/10.1016/s0926-3373(96)00102-6.

Giordanino, F., Vennestrøm, P., Lundegaard, L., Stappen, F., Mossin, S., Beato, P., Bordiga, S. and Lamberti, C. (2013). Characterization of Cu-exchanged SSZ13: a comparative FTIR, UV-Vis, and EPR study with $\mathrm{Cu}-\mathrm{ZSM}-5$ and $\mathrm{Cu}-\beta$ with similar $\mathrm{Si} / \mathrm{Al}$ and $\mathrm{Cu} /$ Al ratios. Dalton Transactions 42(35): 12741. DOI: https://doi.org/10.1039/c3dt50732g.

Hashimoto, S. (2003). Zeolite photochemistry: impact of zeolites on photochemistry and feedback from photochemistry to zeolite science. Journal of Photochemistry and Photobiology C: Photochemistry Reviews 4(1): 19 - 49. DOI: https://doi.org/10.1016/ s1389-5567(03)00003-0.

Heinemann,H.(1981). Technologicalapplicationsofzeolites in catalysis. Catalysis Reviews 23(1 - 2): 315 - 328. DOI: https://doi.org/10.1080/03602458108068081.

Henderson, C. and Taylor, D. (1977). Infrared spectra of anhydrous members of the sodalite family. Spectrochimica Acta Part A: Molecular Spectroscopy 33(3 - 4): 283 - 290. DOI: https://doi. org/10.1016/0584-8539(77)80032-9.

Jiang, B., Jiang, N. and Chang, Y. (2020). Synthesis of highly active $\mathrm{Cu}(\mathrm{I})-\mathrm{Y}(\mathrm{III})-\mathrm{Y}$ zeolite and its selective adsorption desulfurization performance in presence of xylene isomers. Petroleum Science 18(1): 295 - 306. DOI: https://doi.org/10.1007/s12182-020-00531-0.

Juneau, M., Liu, R., Peng, Y., Malge, A., Ma, Z. and Porosoff, M. (2020). Characterization of metal-zeolite composite catalysts: determining the environment of the active phase. Chemcatchem 12(7): 1826 - 1852. DOI: https://doi.org/10.1002/cctc.201902039.

Kallo, D. (2001). Applications of natural zeolites in water and wastewater treatment. Reviews in Mineralogy and Geochemistry 45(1): 519 - 550. DOI: https://doi. org/10.2138/rmg.2001.45.15.

Kannangara, I., Jayawardhana, Y., Munasinghe, E., Rajapakse, A., Bandara, A., Weerasooriya, R. and Jayarathna, L. (2020). Synthesis and characterization of nano zeolite-A with aid of sodium dodecyl sulfate (SDS) as particle size-controlling agent. Colloids and Surfaces A: Physicochemical and Engineering Aspects 589: 124427. DOI: https://doi.org/10.1016/j. colsurfa.2020.124427.
Karge, H. and Beyer, H. (1991). Introduction of cations into zeolites by solid-state reaction. Studies in Surface Science and Catalysis, 69(0167 - 2991): 43 - 64. DOI: https://doi.org/10.1016/s0167-2991(08)61555-4.

Katsuki, H. (2001). Microwave versus conventionalhydrothermal synthesis of $\mathrm{NaY}$ zeolite. Journal of Porous Materials 8(1): 5 - 12. DOI: https://doi. org/10.1023/a:1026583832734.

Kosobucki, P., Kruk, M. and Buszewski, B. (2008). Immobilization of selected heavy metals in sewage sludge by natural zeolites. Bioresource Technology 99(13): 5972 - 5976. DOI: https://doi.org/10.1016/j. biortech.2007.10.023.

Kustov, L. (2020). New horizons in zeolites and zeolitelike materials. Crystals 10(8): 714. DOI: https://doi. org/10.3390/cryst10080714.

Lutz, W. (2014). Zeolite Y: synthesis, modification, and properties - a case revisited. Advances in Materials Science and Engineering 2014: 1 - 20. DOI: https://doi. org $/ 10.1155 / 2014 / 724248$.

Mihai, O., Widyastuti, C., Kumar, A., Li, J., Joshi, S., Kamasamudram, K., Currier, N. W., Yezerets, A. and Olsson, L. (2013). The effect of $\mathrm{NO}_{2} / \mathrm{NO}_{x}$ feed ratio on the $\mathrm{NH}_{3}$-SCR system over $\mathrm{Cu}$-zeolites with varying copper loading. Catalysis Letters 144(1): 70 - 80. DOI: https:// doi.org/10.1007/s10562-013-1133-0.

Mohamed, E., Awad, G., Zaitan, H., Andriantsiferana, C. and Manero, M. (2017). Transition metalsincorporated zeolites as environmental catalysts for indoor air ozone decomposition. Environmental Technology 39(7): 878-886. DOI: https://doi. org/10.1080/ 09593330.2017.1315457.

Moliner, M., Franch, C., Palomares, E., Grill, M. and Corma, A. (2012). Cu-SSZ-39, an active and hydrothermally stable catalyst for the selective catalytic reduction of $\mathrm{NO}_{\mathrm{x}}$. Chemical Communications 48(66): 8264. DOI: https://doi.org/10.1039/c2cc33992g.

Moore, S.M., Rintoul, R.C., Walker, R., Chilvers, E.R., Haslett, C. and Sethi, T. (1998). The presence of a constitutively active phosphoinositide 3-kinase in small cell lung cancer cell mediates anchorage-independent proliferation via a protein kinase $\mathrm{B}$ and p70s6kdependent pathway. The Journal of Cancer Research 58(22): 5239 - 5247. PMID: 9823338.

Moshoeshoe, M., Nadiye-Tabbiruka, M. and Obuseng, V. (2017). A review of the chemistry, structure, properties and applications of zeolites. American Journal of Materials Science 7(5): 196 - 221. 10.5923/j. materials.20170705.12.

Nagy, A., Harrison, A., Sabbani, S., Munson, R.S., Jr, Dutta, P.K. and Waldman, W.J. (2011). Silver nanoparticles embedded in zeolite membranes: release of silver ions and mechanism of antibacterial action. International Journal of Nanomedicine 6: 1833 - 1852. DOI: https:// doi.org/10.2147/IJN.S24019.

Panzarella, B., Tompsett, G., Yngvesson, K. and Conner, W. (2007). Microwave synthesis of zeolites. 2. effect of vessel size, precursor volume, and irradiation method. The Journal of Physical Chemistry B 111(44): 12657 - 12667. DOI: https://doi.org/10.1021/ jp072622d. 
Pavelić, K., Hadžija, M., Bedrica, L., Pavelić, J., Dikić, I., Katić, M., Kralj, M., Bosnar, M. H., Kapitanović, S., Poljak-Blaži, M., Križanac, S., Stojković, R., Jurin, M., Subotić, B. and Čolić, M. (2001). Natural zeolite clinoptilolite: new adjuvant in anticancer therapy. Journal of Molecular Medicine 78(12): 708 720. DOI: https://doi.org/10.1007/s001090000176.

Reyes, C., Williams, C. and Alarcón, O. (2013). Nucleation and growth process of sodalite and cancrinite from kaolinite-rich clay under low-temperature hydrothermal conditions. Materials Research 16(2): 424 - 438. DOI: https://doi.org/10.1590/s1516-14392013005000010.

Sultana, A., Nanba, T., Sasaki, M., Haneda, M., Suzuki, K. and Hamada, H. (2011). Selective catalytic reduction of $\mathrm{NO}_{x}$ with $\mathrm{NH}_{3}$ over different copper exchanged zeolites in the presence of decane. Catalysis Today 164(1): 495 499. DOI: https://doi.org/10.1016/j.cattod.2010.11.036.

Tago, T., Konno, H., Nakasaka, Y. and Masuda, T. (2012). Size-controlled synthesis of nano-zeolites and their application to light olefin synthesis. Catalysis Surveys from Asia 16(3): 148-163. DOI: https://doi.org/10.1007/ s10563-012-9141-4.

Tsai, Y., Huang, E., Li, Y., Hung, H., Jiang, J., Liu, T., Fang, J. and Chen, H. (2021). Raman spectroscopic characteristics of zeolite group minerals. Minerals 11(2): 167. DOI: https://doi.org/10.3390/min11020167.

Valdés, M., Pérez-Cordoves, A. and Díaz-García, M. (2006). Zeolites and zeolite-based materials in analytical chemistry. Trac Trends in Analytical Chemistry 25(1): 24 - 30. DOI: https://doi.org/10.1016/j.trac.2005.04.016.

Valtchev, V. and Tosheva, L. (2013). Porous nanosized particles: preparation, properties, and applications. Chemical Reviews 113(8): 6734 - 6760. DOI: https://doi.org/10.1021/cr 300439k.

Walcarius, A. (1999). Factors affecting the analytical applications of zeolite modified electrodes: indirect detection of nonelectroactive cations. Analytica Chimica Acta 388(1-2): 79-91. DOI: https://doi. org/10.1016/s0003-2670(99)00095-1.

Wopenka, B., Freeman, J. and Nikischer, T. (1998). Raman spectroscopic identification of fibrous natural zeolites. Applied Spectroscopy 52(1): 54 - 63. DOI: https://doi.org/10.1366/0003702981942636.

Yang, H., Downs, R., Evans, S., Jenkins, R. and Bloch, E. (2012). Rongibbsite, $\mathrm{Pb}_{2}\left(\mathrm{Si}_{4} \mathrm{Al}\right) \mathrm{O}_{11}(\mathrm{OH})$, a new zeolitic aluminosilicate mineral with an interrupted framework from Maricopa County, Arizona, U.S.A. American Mineralogist 98(1): 236 - 241. DOI: https://doi. org/10.2138/am.2013.4252.

Yu, Y., Xiong, G., Li, C. and Xiao, F. (2001). Characterization of aluminosilicate zeolites by UV Raman spectroscopy. Microporous and Mesoporous Materials 46(1): 23 - 34. DOI: https://doi.org/10.1016/ s1387-1811(01)00271-2.

Zaarour, M., Dong, B., Naydenova, I., Retoux, R. and Mintova, S. (2014). Progress in zeolite synthesis promotes advanced applications. Microporous and Mesoporous Materials 189: 11 - 21. DOI: https://doi. org/10.1016/j.micromeso.2013.08.014.

Zimmermann, N. and Haranczyk, M. (2016). History and utility of zeolite framework-type discovery from a data-science perspective. Crystal Growth and Design 16(6): 3043 - 3048. DOI: https://doi.org/10.1021/acs. cgd.6b00272. 